\title{
AZ ELEKTROMOS HAJTÁSÉ A JÖVŐ? MIKOR, HOL, HOGYAN ÉS MENNYIÉRT?
}

\author{
Tóth István Tibor
}

\begin{abstract}
Absztrakt: Az a meglátásom, hogy sajnos elég sok elfogult, valamely szempontból prekoncepciós „elemzés” létezik és születik a témában, melyek számításában jelentős hiányosságokra utaló eredmények is szerepelnek. Mindez alkalmas az arra fogékony érdeklődőket félrevezetni, gondolataiban összezavarni, esetleg irányítani. Mert könnyebb az érdemi kritikai értékelésnél egy hivatkozás alkalmazása. Célom nem a meggyőzés és az irány megjelölése, inkább ellenkezőleg, a szükséges mértékü elbizonytalanítás, az elmélkedésre ösztönzés, hogy próbáljuk meg több szempontból is megvizsgálni a címbeli, korunkban egyre inkább divat- és üzletijelleget öltő témakört. Ezt szolgálják a kérdések és a kérdésekben megfogalmazódó következtetések sora is. Több szem többet lát, ha kinyitják, talán a veszélyekből és a lehetőségekből egyaránt.
\end{abstract}

\begin{abstract}
My view is that, unfortunately, there are a lot of biased, somewhat preconceptual "analyzes" exist and are born on the subject electric vehicle. The calculations of these theories also show significant shortcomings, and with their partial truths they are capable of misleading, confusing, or guiding those who are receptive to it. It is more convenient and unfortunately, in many cases seems to be sufficient, to use a well-known, or often used, trendy reference instead of meaningful critical evaluation and thought. My goal is not to persuade and to direct the direction, rather to the extent of the uncertainty needed, to encourage reflection, to try to examine the subject matter, which is becoming more and more fashionable in our age. This is also served by a series of questions and conclusions in the questions. Several eyes see more when they open them, perhaps from the dangers and opportunities as well. That is why I deliberately interpret the directions of development differently and make a somewhat different principle comparison than usual.
\end{abstract}

Kulcsszavak: hatásfok, fejlesztési irányok, feltételek, következmények

Keywords: efficiency, development directions, conditions, consequences

\section{Bevezetés}

Hogyan lehet javítani a közlekedés hatásfokát? Mi a közlekedési eszközök és a közlekedés hatásfoka? Hatékonyság=hatásfok?

A hatásfok egy pontosabban definiált fogalom, mégis vitatható, amíg a hozzá hasonló hatékonyság egy másik, jóval szélesebb körben használt és kevésbé szigorúan behatárolt értelmezés. A hatékonyság változatos szakterületi skálán használatos, eltérő definíciókkal. A különbségek a megtévesztésre itt is kiválóak. Erre egy érdekes példa az internetből (ami persze, mint a példák általában, sántít, de hátha elgondolkodtat). „A kerékpárral közlekedés hatásfoka mondjuk a befektetett energia 80\%-a. Ha egy kerékpáros elindul egy $300 \mathrm{~km}$-es túrára és naponta 8 órát teker, 16-ot pihen, akkor a hatékonysága 33,3\%." (gyakorikerdesek.hu).

A közlekedés, személyek és áruk szállítását különböző müszaki eszközökkel végzö gazdasági, szolgáltató tevékenység. (Révai új lexikona)

A közlekedés azon intézmények és eszközök összessége, amely személyek, javak és hírek szállítására szolgálnak, céljuk üzleti érdekben, müvelődési, vagy politikai tekintetben szükséges kapcsolatokat lehetővé tenni. (Révai nagy lexikona)

Az utazás azon cselekvés, amikor valaki utazik valahová (Magyar értelmező kéziszótár). Ilyen értelemben a közlekedés szinonimája. Személyek vagy tárgyak 
mozgását jelenti. A közlekedés egyik célja a szállítás, amikor egy közlekedési eszköz segítségével embert, árut, vagy szállító vezetékek segítségével információt, energiahordozókat meghatározott helyre továbbítanak.

A fenti ízelítő gondolatok is jól mutatják, hogy mennyi független irány választható a közlekedés jobbá, a kor szellemében szólva, fenntarthatóvá tételéhez. Ezek közül csak az egyik irány az eszközök hajtásrendszerének a fejlesztése, ami szinte biztosan nem is a leghatékonyabb eleme a rendszernek, de ez már egy másik elemzés lehet például a „Smart Traffic” keretein belül.

\subsection{A hajtásrendszerek fejlesztési irányait befolyásoló tényezők.}

A hajtásrendszerek alatt itt a tradicionális belsőégésủ motoros és az alternatív üzemü hajtások teljes körét értem. Ez a változatosság, az érdekeltségek, irányelvek stb. hátterével garantálja a meghatározás bonyolultságát, de a csoportosítás segíthet, legalább új szemszögek feltárásával.

A lakonikus, vagy ironikus, esetleg ikonikus válasz a befolyásoló tényezőkre egyszerüen: pénz, pénz, pénz és pénzek.

1. Pénz a szükséges ráfordítások oldaláról nézve, azaz melyik megoldás lenne a legolcsóbban, leggyorsabban kifejleszthetö, melyik valósítható meg a legkisebb beruházási és várható gyártási költségekkel, melyiknek a legolcsóbb a piacra lépési költsége.

2. Pénz a finanszírozás oldaláról nézve, azaz melyikhez szerezhető egyéb forrás, támogatások, pénzügyi befektetők stb.

3. Pénz a bevételi és nyereségtermelő oldalról nézve, azaz melyik a leggyorsabban, legtöbb hasznot biztosító, esetleg melyiket lehet a legkisebb ráfordítással a leghosszabb ideig kihasználni, vagyis melyik a várható legnagyobb nyereségtömeget adó.

4 Pénz az egyéb jövedelmező kapcsolódó, kapcsolható termékkörök, valós és virtuális üzletek létrehozásának költségei és várható eredményei oldaláról nézve.

Ezeket a szempontokat müszaki, társadalmi, környezetvédelmi stb. kérdések kizárólag „forintosítva”, „,monetáris szinten” érintik és egyáltalán nem feltétel, hogy technikailag és/vagy más szempontból is hasznos, előre mutató, és fenntartható legyen a létrehozott termék.

Mivel egyik tényező sem kötődik szignifikánsan a másikhoz, sőt akár ellentétes feltételeket is igényelhetnek (például nagyobb intenzitású támogatást nyerhetett hamarabb egy kimutathatóan nem eredménytermelő beruházás, mint egy nyereségorientált), ezért kívülről nézve bizonytalan a kimenet.

Az 1. csoportnál is lehet tovább csoportosítani, azaz rendszerszinten, vagy adott, saját hatáskörön belül keresni a legolcsóbb, leggyorsabb megoldást, autonóm, szigetjellegü, vagy kiterjedt hálózati felhasználást feltételezve. Lehet kizárólag a motor müködését fejleszteni, de lehet átalakítani a rendelkezésre álló saját, vagy rendeletileg szabályozott egyéb üzemanyag felhasználására. Első hallásra ez inkább „sufni tuningnak" tünhet, de az innováció egyik természetes generátora, sokszor elképesztő (+/-) eredmények forrása. A szükség, nagyúr. Születtek, születnek 
optimalizált üzemü motorok, vezérlések jelentősen kevesebb fogyasztással, de alternatív üzemanyagú (gőz, gáz, biogáz, biodízel, etanol, bioetanol stb.) hajtások egyaránt, amik közül különböző okok miatt (időhiány, érdektelenség, szabadalmi terhek...) a legtöbb el sem jut, el sem jutott a piacig.

A 2. csoportnál komoly szerepet kap a politika, az aktuális gazdasági helyzet, de a kockázati tőke állapota is. Még ebben a csoportban sem feltétlenül a piaci megjelenés a cél. A forrás elnyeréséhez kapcsolódó feltételek elég határozottan meghatározhatják a fejlesztés irányát és mértékét egyaránt, ami környezetvédelmi szempontokat is célul tüzhet.

A 3. csoport az egyértelmüen piaci indíttatású fejlesztések. Itt sokat számít a finanszírozói háttér, ami a megtérülést és a nyereséget követeli. Az időtényező miatt sokszor nem az adott irányban elérhetö legjobb valósul meg, a különbözö elöírásoknak is csak éppen, vagy trükkösen megfelelöség lehet a cél, melyet szentesít az így hamarabb jelentkező értékelhető mértékủ profit.

A 4. csoport a legbonyolultabb. Itt már olyan rendszerszintü összefüggések alapján indulnak és folynak fejlesztések, amelyek közvetlen eredménye önmagában akár érdemtelen lenne a megvalósításra, mégis a közvetett eredmények miatt piacra kerül, sőt jelentős termelési mértéket is elérhet. Gondoljunk arra, hogy monopol szereplőként a világpiacon jól előkészítve, megfelelö „csomagolásban” komoly felárral, hozzáadott értékkel értékesíthető egy termék a kezdetekben. Amennyiben ez, ráadásul egyéb külső, pl. EU-s támogatásokkal, hosszabb ideig fenntartható, akkor a kezdő országnak megéri finanszírozni, akár állami támogatásokkal és megrendelésekkel is a foglalkoztatottság és a vele járó másodlagos bevételek, polgári (választói) elégedettség több mint elegendő indok. Ezzel csak az a gond, hogy egyeseknek, egyes termékekkel, egyszer és korlátozott időre adatik meg. A következmények pedig teljes tévútra terelhetik a műszaki fejlesztést gazdasági és környezetvédelmi oldalról egyaránt. Miután egy csoport meggazdagszik egy termékkörön, és mások is el tudják kezdeni gyártani azt, rá kell ébredniük, hogy ilyen méretekben már csak veszteséges és akár környezetterhelő is az adott megoldás. Lehet, hogy ez a törvényszerü? Hasonló játszódott le a lovaskocsikkal, a gőzgépekkel, a pneumatikus hajtású jármüvekkel és az elektromos járművekkel egyaránt a XX. század elején. Akkor a belsőégésű motorok győztek, sőt váltak megoldássá, megmentővé. Az okokat lehet elemezni, mert következtethetünk belőlük a mai trend későbbi alakulására, de ez megint egy másik értekezés lenne.

\subsection{A tisztán elektromos hajtású jármủvek.}

Napjaink nagy reményének kikiáltott, nagy múlttal rendelkező, de történelmében egyszer már komoly veszteséget elszenvedő konstrukció. 1828-ban építette Jedlik Ányos az első villanymotort, 1830-ban már müködött az első elektromos hajtású hintó, 1899-ben az első 100 km/h-nál gyorsabb autót villamos hajtás repítette, 1900ban az USA-ban gyártott 4192 autóból 1575 db villamos hajtású volt az $1681 \mathrm{db}$ gőzautó és $936 \mathrm{db}$ benzines mellett. (factually.gizmodo.com) 1912-ben az üzemeltetett elektromos autók száma elérte a 30000 darabos csúcsot és feltalálták az önindítót, ami akkorát rántott a belsőégésű motorok terjedésén, hogy „az 1930-as 
évek közepére az árammal hajtott gépkocsik voltaképpen eltüntek a föld színéről”. (alternativenergia.hu) Az 1970-es évekig csak elszigetelt kisebb próbálkozások voltak, amikor is az újabb olajválság megrázta az elektromos közúti jármüfejlesztést, de az igazi feléledést csak a XXI. század hozta.

Részben párhuzamos a villamosvasút, a villamosmozdony és a trolibusz életpályája is, de a hálózati jelleg és a közösségi közlekedés miatt talán kevésbé, bár esetenként éppen még inkább hullámzó. A fö, hogy ezek is megélhették a reneszánszukat korunkban.

Ahogy a történelem is megmutatta el kell különíteni a hálózatról müködtetett és az önjáró, autonóm jármüveket, igaz az utóbbi években már többen azon dolgoznak, hogy egymásra találjon a két struktúra, amivel közösíteni szeretnék mindkét rendszer előnyeit. Azért felmerül a kérdés, hogy lehet-e csak az előnyöket közösíteni a hátrányok nélkül? Az elkülönítés alapvetően az üzemi feszültségben és a hatótávban jelentkezik, de ott az eszköz és az energiaellátás, illetve az egyéb infrastrukturális beruházási-, fenntartási-, karbantartási- és pótlási költségek, követelmények, a hasznos térfogat és terhelhetőség, a forgalmi flexibilitás, az érintésvédelem, rendelkezésre állási képesség, hatásfok, rekuperációhasznosulás, üzemeltetést korlátozó egyéb feltételek is.

$\mathrm{Az}$ autonóm elektromos hajtás kezdeti elöretörésének a végét egyrészt az alternatív megoldások térnyerése, másrészt az energiatárolás korlátjai gátolták és törték meg közel száz évvel ezelött.

Akkor nehezek voltak az akkumulátorok, rövid volt a hatótáv és túl sok időt vett igénybe az újratöltés. Mi a helyzet most?

Most, nehezek az akkumulátorok, rövid a hatótáv és sok időt vesz igénybe az újratöltés. Ezen felül, bonyolult vezérlésre (BMS) és höfokszabályozásra van szükség, a jármü árában jelentős tétel az akkumulátor ára és bizonytalan a várható élettartama.

Az akkumulátor technológia fejlődése vitathatatlan, de az alapvető gondok mintha nem változtak volna az elmúlt évszázadban. Az elért és belátható időn belül elérhető energiasürüség az általánosan elterjedésben lévő lítium alapú akkumulátorok esetében is nagyságrendekkel alacsonyabb a fosszilis üzemanyagokénál.

Az akkupakk komplett tömegével számolva, figyelembe véve a hütés-fütést és más kiegészítő elemeket is, jelenleg jó, ha az energiasürüség $120 \mathrm{Wh} / \mathrm{kg}$, míg a dieselolaj esetén ez az érték 8-9000 Wh/kg. Igen, tudom, figyelembe kell venni a felhasználás hatásfokát is, hogy össze lehessen vetni a kettőt.

Mivel rendelkezésre állnak valós mért fogyasztási értékek, ezért az elmélet helyett, mellett ezekhez a valós $\mathrm{Wh} / \mathrm{km}$ értékekhez folyamodok az összevetés érdekében. Mondhatnám azt is, hogy saját mérések alapján, de idézhetnék itt száz és száz publikált mérésadatot úgy az elektromos, mint a diesel autók fogyasztásáról. A közkézen forgó adatok szerint a kisebb teljesítményü személyautóknál az elektromosok 100-150 Wh/km, a dieselek 4-5 1/100km $(388-486 \mathrm{Wh} / \mathrm{km})$ fogyasztást mutatnak. A nagyobb teljesítményüeknél ez az érték 180-230 Wh/km, illetve 7-10 1/100km (680-972 Wh/km). 
Ez azt jelenti, hogy durván négyszer kisebb a fajlagos energiaszükséglete az elektromos autónak a dieselhez képest, míg az ,üzemanyag” energiasürüségében a különbség nyolcvanszoros. 4 kontra 80 , azaz azonos hatótáv érdekében hússzor akkora tömegben kell energiahordozó egy elektromos autóba, mint egy dieselbe. Ez azonban még mindig nem fedi a valóságot, mert a lítium akkumulátor teljes lemerítése az élettartamát jelentősen csökkentheti, ezért gyártótól függően elöírják, vagy eleve szoftveresen lehatárolják a kapacitás 20-50 \%-át, ami a tömeg szempontjából további 25-100 \%-ot jelent. A dieselnél erre az aranytartalékra nincs szükség, de ha a 60 literes tankban hagyunk 1 litert, nincs komolyabb következmény.

\begin{tabular}{|c|c|c|l|l|}
\hline & $\begin{array}{l}\text { Energia } \\
\text { súrüség } \\
\text { Wh/kg }\end{array}$ & Megújuló & Ára & Infrastruktúra \\
\hline Ólomakkumulátor & 100 & Részben & Irreleváns & Részben \\
\hline Lítium akkumulátor & 140 & Részben & Jelentős & NINCS \\
\hline Metál hibrid akkumulátor & 100 & Részben & Irreleváns & Részben \\
\hline Hidro-pneumatikus & $600-1200$ & IGEN & Ismeretlen & Részben \\
\hline Mechanikus KERS & 120 & IGEN & smeretlen/Irreleváns & VAN \\
\hline Fosszilis & $8-9000$ & Részben & Megszokott & VAN \\
\hline
\end{tabular}

Forrás:Saját szerkesztés (2019)

\section{2.táblázat: Összehasonlító adatok}

\begin{tabular}{|c|c|c|c|c|}
\hline & $\begin{array}{c}\text { Fajlagos fogyasztás } \\
{[\mathrm{Wh} / \mathrm{km}(1 / 100 \mathrm{~km})]}\end{array}$ & $\begin{array}{c}\text { Szükséges, üzemanyag” tömege } \\
\text { tartalék } \\
{[\%]}\end{array}$ & $\begin{array}{c}\text { Töltésidő }[\mathrm{h}] \\
1000 \mathrm{~km} \text { úthoz } \\
{[\mathrm{kg}](140 / 8-9000)}\end{array}$ & $(\mathrm{e} 3 \mathrm{~kW}-170 \mathrm{~kW})$ \\
\hline Kis e-autó & $100-150$ & $20-50$ & $893-2143$ & $0,58-50$ \\
\hline Kis diesel & $388-486(4-5)$ & $1-5$ & $43,5-64$ & $0,03-0,05$ \\
\hline Nagy e-autó & $180-230$ & $20-50$ & $1607-3286$ & $1,06-76,7$ \\
\hline Nagy diesel & $680-972(7-10)$ & $1-5$ & $76,1-128$ & $0,05-0,1$ \\
\hline
\end{tabular}

Forrás:Saját szerkesztés (2019)

És jöhet az ide vonatkozó „fajsúlyos” kérdések sora. Mi van a környezetterheléssel? Mi lesz, ha elfogy az olaj? Melyik a fenntartható? Well to wheel összevetésben melyiknek milyen a hatásfoka, emissziója? ... A sokszor használt externáliák internalizálása módszerei. 
Igen messze vezetnek ezek a kérdések is és nagyon vitás az értékelésük, ami megint újabb értekezést érdemelne.

\subsection{Elektromos infrastruktúra és egyéb vonzatok.}

A plug-in elektromos hibrid és az autonóm elektromos hajtás egyaránt igényli a töltéshez a megfelelö energiaellátást. A felsővezetékről müködtetett eszközparknál pedig alapfeltétel a megfelelő hálózat kiépítése. Ez utóbbi rendszerekről jelentős adatbázis és sokéves tapasztalat áll rendelkezésre az elektromos közösségi közlekedést fenntartó társaságoknál. Az egyik ok, ami miatt a fajlagos költsége magasabb a trolibusznak a buszénál, az éppen az elektromos ellátással kapcsolatos költségelemek. Ez motiválja azt is, hogy az EU Horizon 2020 és a CIVITAS 2020 programok részeként az ELIPTIC projekt egyik kiemelt kutatási témája a buszvonalak kiváltása trolibuszvonalak meghosszabbításával felsővezeték építés nélkül hibrid trolibuszok alkalmazásával. (elliptic-project.de)

A már létező, kiépített rendszerek esetében egyenlöre gyökeres változás nem várható, nem terveznek meghatározó mértékü bővítést, vagy fejlesztést. Azonban, éppen a menetrend betartása, a megállók és a városi közlekedés miatt, pontosan ezen a területen kamatoztatható leginkább az elektromos hajtás rekuperációs képessége, ezért egyre erősödik a szándék a hibrid és autonóm elektromos hajtású buszok bevezetésére, ami nagyságrendje miatt mégis magával vonja az energiaellátó hálózat fejlesztésének a kérdését, ami a jármükoncentráció miatt egyszerübben kivitelezhető, ha elegendő kizárólag a buszgarázsban, busztelepen elvégezni az akkumulátorok töltését. Amennyiben a vonalakon is töltésre lesz szükség, akkor az már érintheti a városi elektromos hálózatot, annak fejlesztését is igényelheti a jelentősebb töltési teljesítményszükségletü töltőpontok miatt. Akár egy önálló új elektromos hálózat kiépítésére is sor kerülhet, ami a közösségi közlekedés érdekében támogatható lehet, csak legyen hozzá akarat és forrás.

A városi terítő teherfuvarozás elektromosítása is racionálisnak tünik első pillantásra. Ha ott is megvalósítható a telephelyi töltés, akkor a cégek telephelyén valószínüleg megvalósítható a nagyobb elektromos teljesítmény biztosítása, bár ez is függ a helyi adottságoktól, a jármüpark méretétől.

Összehasonlíthatatlanul több és nagyobb a kérdőjel a személyautókkal kapcsolatban. Milyen mennyiségre kell felkészülni? Hány töltési pontot kell kialakítani? Milyen teljesítményüek lesznek ezek a pontok? Milyen kiegészítő szolgáltatások, juttatások kapcsolódnak a töltéshez? Mennyibe kerül a kialakítás és mennyibe kerül az üzemeltetés? Ki, milyen feltételekkel fogja fenntartani?

Jelenleg is jogosak ezek a kérdések, de az alacsony jármüszám, politikai és marketing célok miatt még nem kerültek terítékre. Az elektromos autók száma pedig nő. A magyarországi zöld rendszám bevezetése hasznos ebből a szempontból, mert jól mutatja a változást, lehetővé teszi a tervezést. A rendszámhoz kapcsolódó meghirdetett kedvezményekről azonban már most látható, hogy nagyobb számok mellett nem lesznek fenntarthatók. 


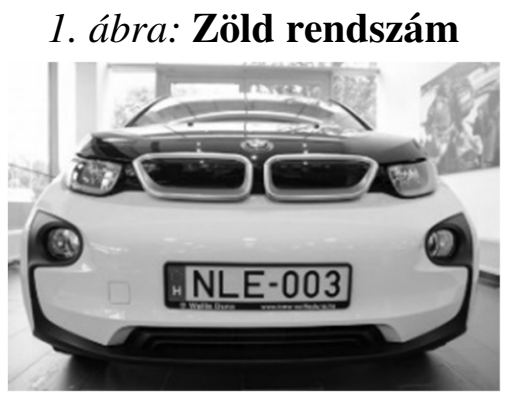

Forrás: vezess.hu

De mekkorák is ezek a nagyobb számok és mikorra várható a megjelenésük? Napjaink legagresszívabb elektromosautó gyártója bejelentette, hogy 2020-tól már évi 500000 e-autót fog legyártani. A többi, jóval nagyobb autógyártónál is rendelkezésre áll már régóta a technológia, csak veszteségessége miatt nem erőltették a forgalmazást. „Marchionne úr reméli, minél kevesebbet sikerül értékesítenie a vállalatnak a Fiat 500e nevü - a sima 500-asra épülö - tisztán elektromos árammal müködő kisautóból, mert az 14 ezer dolláros (3,1 millió forintos) veszteséget jelent a cégnek darabonként." (autoblog.hu) Most azonban rá vannak kényszerítve a piacrész megörzése érdekében, így 2020-tól évente akár évi 3-5 millió e-autó is készülhet. Ezekből ugyan nem kerül sok Magyarországra, de ami jön, az nagy valószínüséggel a fővárosban koncentrálódik.

Mi lenne, ha az ösztönzés érdekében Budapesten telepíteni kellene $1000 \mathrm{db}$ gyorstöltőt és $100 \mathrm{db}$ villámtöltőt?

A jogi feltételeket, bármily érdekesek is, itt és most nem feszegetem.

A fizikai feltételeket is több csoportra kell bontani:

- Fizikai hely biztosítása. A töltőoszlopoknak helyet kell biztosítani. Egy oszlophoz érdemes legalább kettő parkolóhelyet rendelni, ami 1100 oszlop esetén $2200 \mathrm{db}$ parkolóhelyet jelent (a jelenlegi közel 65000 parkolóhelyből), lehetőség szerint a magasabb kihasználtságú „,közkedvelt” zónákban. Amennyiben a közbiztonsági és vagyonvédelmi elveket is figyelembe kívánjuk venni, akkor ezeket a helyeket jól megkülönböztethetően el kellene határolni és értékvédelmi rendszerrel ellátni. Másik kérdés, hogy kizárólag e-autók töltésére képes töltőberendezéseket telepítsenek, vagy multifunkciós egységeket, amikkel e-kerékpárok és egyéb eszközök is tölthetők lennének. Ebben az utóbbi esetben a helyigény is megváltozik, úgy a méret szempontjából, mint elhelyezkedés, hozzáférés és funkcionális kialakítás (fedett, elkerített, örzött...) terén. 
2. ábra: Egy töltő két parkolóhelyhez.

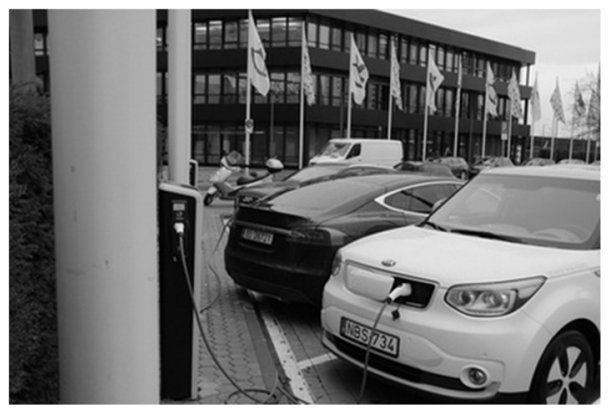

Forrás: galeria.totalcar.hu

- Hálózati kapcsolódás. A töltőoszlopokhoz megfelelö teljesítménnyel bíró tápvezetéket kell rendelni. A vezetékek telepítése földkábeles legyen, lehetőleg a legrövidebb hosszon, a meglévő közmüvek megzavarása nélkül, minimális telepítési munkával kivitelezhetően.

- Energia biztosítása. A töltőoszlop teljesítményéhez igazodó táp rendelkezésre bocsátása. A gyorstöltő esetében kettő jármü egyidejü töltéséhez, 4 óra alatt legalább $40 \mathrm{kWh}$-át kell leadni, ami $10 \mathrm{~kW}$ teljesítményt feltételez minimum. A villámtöltő esetében ez legalább 100 $\mathrm{kW}$ teljesítmény szükséglet. Ez a hálózati kapcsolódás szempontjából is meghatározó lehet a gerincvezetékek hálózatához illeszkedés miatt. Fontos meghatározni továbbá, hogy adott területen rendelkezésre áll-e az áramszolgáltató részéről elegendő kapacitás, vagy komolyabb beruházást igénylő bővítésre lenne szükség. Csak erre az 1100 töltőoszlopra 20 MW feletti teljesítmény szükséges!

- Informatikai kapcsolat. A töltőoszlopokat közös informatikai hálózatba érdemes kötni az elérhetőség, elszámolás, biztonság stb. támogatása érdekében. Ez megoldható GPRS alapon, de megbízhatóbb, ha kábeles csatlakozás kerül kiépítésre.

A gazdasági feltételeket a fizikai feltételek szerinti csoportosítás mentén sorolom.

A fizikai helybiztosítás első, közvetlen gazdasági hatása a helyek funkciómódosulásának a következménye. Egy parkolóhely éves bevételképző képessége jó helyen több mint 1 millió forint, ami alapján a 2200 hely miatt a kiesés éves szinten 2-2,5 milliárd forint. Amennyiben nem történik díjfizetés valamilyen címszóval és a terület eddigi haszonélvezője felé nem jelentkezik térítés, akkor ezt is pótolni kell a költségvetésben valamilyen módon. Ha térítéses lesz a töltő használata, akkor meg kell határozni a tarifaképzés elvét, valamint az üzemeltető és a terület tulajdonosa közötti bevételmegosztást, vagy egyéb térítési elvet is rögzíteni kell.

A beszerzés költségeit jelentős mértékben befolyásolja a töltő típusa. A legolcsóbb konstrukciók is 4 millió forint körül vannak, amik nem tudják teljesíteni a villámtöltés, azaz a 20 percen belüli $80 \%$-os töltöttség feltételeit. A pontos értéket csak hivatalos ajánlatkérés alapján lehet meghatározni, de irányszámként az 1000 
oszlopra komplexitás, funkcionalitás függvényében 4-10 milliárd forint között lehet tervezni. Fontos lenne meghatározni az arányokat is, hogy milyen arányban legyen esetlegesen multifunkciós eszköz, amihez a fedett, elkerített, örzött területrész további költségigényt jelent. Ugyanakkor ezt okosan kialakítva, a helyszín jó kiválasztása mellett, további funkciók bevonásával, akár bérbeadással, vagy kapcsolt tevékenység fenntartásával lehet az üzemeltetést egyrészt javítani, másrészt részfinanszírozni.

A kivitelezési költségeket csak a pontos helymeghatározás után lehet érdemben megtervezni. Illeszteni kell a töltőegységeket az elektromos hálózat megfelelő teljesítménnyel bíró részeihez, és a közmü többi eleméhez, különben a bekötés szélsőséges esetben akár az eszköz értékének többszörösébe is kerülhet.

$\mathrm{Az}$ informatikai kapcsolat megteremtése az egyszerübb kérdés. A GPRS kialakítás olcsóbb a beruházás szempontjából, töltőnként megoldható akár 50.000 Ft-ból is, ami összességében ugye 55 millió forint, de ez később az üzemeltetés során bosszulja meg magát úgy költség, mint üzembiztonság és karbantartás terén. A kábeles kapcsolat kialakítása egyértelmüen függ az elhelyezéstől. Javasolt az elektromos bekötéssel egy időben megvalósítani a kivitelezését.

Irányszámnak az 1100 egység bekötésére, kivitelezésére legalább 1,5 milliárd forintot érdemes venni.

Az energia biztosítás kiépítés költségei jelen alapadatok mellett, azaz információ hiányában nem tervezhetők. Amennyiben az energiaszolgáltatónak új transzformátorokat kell telepítenie, vagy nagyobb teljesítményü transzformátort kell üzembe helyeznie, akkor az összes eddigi költséget meghaladó többletköltség jelentkezhet, de szerencsés esetben, jó helyválasztás mellett még el is kerülhető a többséget jelentő gyorstöltők esetében. A 100 db villámtöltő $100 \mathrm{~kW}$-os teljesítményszükséglete azonban akár saját transzformátor telepítést is eredményezhet, ami könnyen további 1 milliárd forint feletti érték is lehet, ráadásul a jelentős teljesítmény miatt az üzemeltetési költségei is fajsúlyosabbak lesznek.

Az üzemeltetési költségek meghatározásánál figyelembe kell venni az eszközök elektromos hálózati alapdíját, a várható energia felhasználást, a szükséges műszaki személyzet és technika költségeit, a takarítási és karbantartási anyagköltségeket és nem utolsó sorban a várható eszközpótlást biztosító amortizációs költségeket, illetve az egyéb, pl. biztosítási, engedélyeztetési, bérleti, ráosztott üzemi, és központi költségeket is.

A várható energiafelhasználás kezdetben nem lesz jelentős a Budapest területén fellelhető elektromos flotta kis száma miatt (kezdetben 500 zöld rendszám lett kiadva). A tervezésnél azonban egy reálisnak is tekinthető maximális kapacitást javasolt figyelembe venni, például $80 \%$-os kihasználtság esetén, oszloponként 2-2 járművel, jármüvenként 4 órás, illetve 20 perces (villámtöltő) töltési idővel $0.8 *(1000 * 10 \mathrm{~kW}+100 * 100 \mathrm{~kW}) * 24 \mathrm{~h}=0,8 * 480.000=384.000 \mathrm{kWh} / \mathrm{nap}, \quad$ ami 365 nappal számolva $384.000 * 365=140.160 .000 \mathrm{kWh} / \mathrm{év}$ fogyasztás. $40 \mathrm{Ft} / \mathrm{kWh}$ bruttó áron számolva ma még talán soknak hangzó éves 5,606 milliárd forintos bruttó energiaköltséget jelent. 
Ez naponta $24.000 * 80 \%=19.200 \mathrm{db}$ kisebb hatótávú és $14.400 * 80 \%=11.500 \mathrm{db}$ nagyobb hatótávú igénybe vevő jármüszámot feltételez, ami a Jedlik Ányos terv célszámai és a fentebbi gondolatmenetem szerint is megteremtődhet, akár csak belföldi háttérből is. Az ilyen mennyiségü eszköz azonban már újabb kérdéseket vet fel az úthasználat és a beígért ingyenes parkolás miatt! Ha például ezt, az esetünkben másodlagos, mondhatni externális hatást, is figyelembe vesszük, akkor városi szinten akár $(19.200+11.500) \mathrm{db} * 10 \mathrm{~h} * 231 \mathrm{nap} * 450 \mathrm{Ft}=31.912 .650 .000 \mathrm{Ft}$, azaz 32 milliárd forint parkolási bevétel kiesés is keletkezhet, amit több, mint nehéz lesz kompenzálni!

Amennyiben ezek alapján határozzuk meg az igénybevételi költségtérítést, akkor kérdés, hogy sokan veszik-e majd igénybe a töltőoszlopok és az elektromos autók eme kapcsolatát. Ha nem ezek szerint számítunk, határozunk meg árat, akkor pedig a közpénzek egy részét a tehetősebbeknek ajándékozzuk a környezetvédelem hangoztatása mellett. Persze ki lehet még számolni, hogy mekkora $\mathrm{CO}_{2}$ kvóta bevétel jön létre, de azon túl, hogy az inkább a kutya vacsorája kategória, mert nem kerül oda, ahol a hiány, vagy a költség keletkezik, még biztosan kevés is lesz, és nem fogja fedezni a veszteségeket.

\section{2. Összegzés}

Komoly szerepe lehet az elektromos hajtásnak a jövőben. A müszaki logika éppúgy támogatja a fejlődését, mint egyes politikai és gazdasági érdekek, de sok megoldandó feladat és eldöntendő kérdés van, amik rossz megoldás esetén ismét előidézhetik a száz évvel ezelöttihez hasonló, vagy annál is súlyosabb hanyatlást.

Biztos, hogy a jelen akkumulátor technológia a jövő?

Meddig lesz elegendő a lítium, a kobalt és milyen áron?

Mennyire környezetbarát ebben a formában az e-autózás?

Képesek vagyunk kiépíteni akár egy 1 milliós hazai e-autó jármüpark hátterét?

Képesek leszünk elegendő energiát biztosítani a személyautók, teherjármüvek és tömegközlekedési eszközök töltésére?

Ha ezt az akkumulátortechnikát használjuk, akkor tényleg a nagy hatótávra nagy akkupakk elv lesz a megoldás és nem egy hibrid?

Megéri kidobni a meglévő globális szénhidrogénes infrastruktúrát és ez nem pazarlás?

Magyarország, mérete miatt a globális trendre nem bír hatással, de saját érdekünk, hogy ne tegyünk olyat, amit később megbánunk.

\section{Irodalomjegyzék}

http://factually.gizmodo.com/about-40-of-american-made-cars-in-1900-were-steam-powe1597522738

http://galeria.totalcar.hu/kozelet/2016/02/03/soul-tura_osszegzo/15?openwith=10967587 http://mno.hu/autopult/egyelore-befellegzett-a-levegos-hibrideknek-1269553

http://szkt.hu/jarmuveink\#villamosok

http://totalcar.hu/magazin/hirek/2013/04/27/lendkerekes_hajtason_dolgozik_a_volvo/ http://www.alternativenergia.hu/az-elektromos-autozas-rovid-tortenete/68280

http://www.autoblog.hu/hirek/a-fiat-14-ezer-dollart-veszit-minden-elektromos-500-ason/ 
http://www.douglas-self.com/MUSEUM/LOCOLOCO/airloco/airloco.htm\#h http://www.eliptic-project.eu/thematic-pillars

http://www.gyakorikerdesek.hu/tudomanyok__alkalmazott-tudomanyok_7351548-hatekonysaghatasfok

http://www.vezess.hu/app/uploads/2016/03/zold-620x414.jpg

https://en.wikipedia.org/wiki/Frank_J._Sprague

https://sg.hu/cikkek/83328/egy-elektromos-f1-lokest-adna-az-elektromos-autoknak

Magyar értelmező kéziszótár(Budapest, 1972) 1435. o.

Révai nagy lexikona 12. kötet (Budapest, 1915) 234 o. (a fogalom korszerüsítésével)

Révai új lexikona XII. (Klc-Ky). Főszerk. Kollega Tarsoly István. Szekszárd: Babits. 2003. 730. o. ISBN 963-955-607-6 